\title{
Caustic Material Ingestion Injuries- Paradigm Shift in Diagnosis and Treatment
}

\section{Amit Katz $^{1 *}$ and Yoram Kluger ${ }^{2}$}

${ }^{1}$ Department of General Thoracic Surgery, Israel

${ }^{2}$ Division of General Surgery, Israel

\begin{abstract}
Despite efforts to reduce exposure to corrosive household products there are still 5,000 new cases of severe caustic material ingestion injuries (CMI) in the United States each year. If managed inappropriately the associated morbidity and mortality are substantial. In this review we will try to highlight the clinical presentation, diagnostic and management of caustic material ingestion injuries. We will focused on the current trends in the evaluation and management of patients that become more conservative compared to previous decades.
\end{abstract}

\section{Introduction}

Despite efforts to reduce exposure to corrosive household products there are still 5,000 new cases of severe caustic material ingestion injuries (CMI) in the United States each year. Injury rate in developing countries is even higher. This injury can result in the associated morbidity and mortality is substantial. Only few high quality prospective studies are available in regard to CMI and many of the current recommendations regarding treatment are based on experts opinion. In this review we will try to highlight the clinical presentation, diagnostic and management of caustic material ingestion injuries.

\section{Epidemiology, pathophysiology and clinical presentation}

Severe immediate and late tissue damage that may progress and consequently develop acute and late complications. If managed inappropriately Caustic ingestion may result in significant injury to the oropharyngeal cavity, larynx, esophagus, and stomach. The majority $(68 \%)$ of cases worldwide are the result of accidental ingestion of caustic substances by children. The remainders of cases are adults with psychiatric disturbances, attempting suicide, or alcoholics $[1,2]$. The type and amount of ingested substance and the time of tissue exposure determine the severity of injury.

In children damage is frequently and relatively minor due to smaller amounts of ingested substance while in adults and especially after suicide attempts injury is often more severe. This is due to larger quantities of the caustic substance ingested [3-5]. Injury caused by alkali or acid results in a different injury pattern. Alkali causes almost no irritation to the oral cavity and therefore larger volumes are swallowed. Alkali materials are thicker leading to lengthier exposure causing progressive liquefactive necrosis injury. This injury may extend over a course of two weeks resulting in thinning of the esophagus lining.

Due to the neutralizing effect of gastric acids and free passage through the pylorus limited exposure time of the gastric and duodenal mucosa eventually may result in less severe injury. Acids induce pain immediately upon contact with oral mucosa. They lack viscosity but induce pyloric spasm and are not neutralizing by endogenous gastric secretion. Accordingly their transit time through the esophagus is rapid and in most cases the damage to the esophagus is limited. On the other hand the duration of exposure to the gastric mucosa is extended leading to coagulative necrosis. However based on our experience and that of others acid can cause significant damage to the esophagus and alkali substances may induce significant injury to the stomach and duodenum [6-9]. It seems that "anatomy preference" of caustic material is related more on viscosity, amount of the ingested material and exposure time to tissue rather than on the agent $\mathrm{pH}$ characteristics proper.
Clinical presentation is highly variable. Patients with minimal ingestion may be asymptomatic but others may experience oropharyngeal, retrosternal or epigastric pain. Shortness of breath, hoarseness and stridor suggest laryngeal injury. Dysphagia, odynophagia and excessive salivation are suggestive of esophageal damage. Abdominal pain; vomiting and hematemesis may suggest gastric damage. Continued pain, peritonitis, tachycardia, persistent leukocytosis, acidosis and pleural effusion should raise the suspicion of perforation [10-16]. The most common early and serious acute complications are perforation and bleeding. Reported mortality approaches $10-20 \%$. Among those sustaining caustic injury in a suicide attempt, mortality may approach $75 \%$.

Delayed complications include stricture and fistula formation (tracheobronchial, gastro colic or even entero-aortic). Long term risk of malignant transformation in the damaged esophagus was also reported. The true incidence of post caustic malignancy is unclear $[17,18]$.

\section{Diagnosis and Treatment}

\section{Initial evaluation}

The initial management should involve careful assessment of the extent of injury. It is important to document the type and quantity of ingested material. A careful assessment of symptoms and signs is paramount. Complaints of dyspnea, dysphagia, excessive salivation, hematemesis or hoarseness suggest severe injury. Forty percent of patients suffer injury to the upper respiratory tract. Dyspnea, stridor or laryngeal edema are signs of significant airway injury. Approximately $5-15 \%$ will need immediate intubation $[19,20]$. Laboratory tests don't always correlate with injury severity but leukocytosis $>20,000 \mathrm{WBC} /$ $\mathrm{ml}$, elevated CRP and $\mathrm{pH}<7.2$ may indicate severe injury [21-23]. Initial chest X-ray may identify pneumoperitoneum, pleural effusion or

*Corresponding author: Amit Katz, MD, Department of General Thoracic Surgery, Rambam Health Care Campus, Haifa, Israel, Tel: 9720502062291; E mail: a_katz@rambam.health.gov.il

Received November 09, 2015; Accepted December 21, 2015; Published December 27, 2015

Citation: Katz A, Kluger Y (2015) Caustic Material Ingestion Injuries- Paradigm Shift in Diagnosis and Treatment. Health Care Current Reviews 3: 152. doi: 10.4172/2375-4273.1000152

Copyright: (C) $2015 \mathrm{Katz}$ A, et al. This is an open-access article distributed unde the terms of the Creative Commons Attribution License, which permits unrestricted use, distribution, and reproduction in any medium, provided the original author and source are credited. 
pneumomediastinum that suggests presence of perforation. The extent of injury that results from caustic ingestion is estimated by endoscopy. First degree burns involve only the mucosa, with localized redness and edema. Second degree burns involve the mucosa and sub- mucosa with blister formation. Third degree burns are characterized by a transmural process with findings of extensive ulceration and necrosis [24,25]. Traditionally early endoscopy (within $12-24 \mathrm{~h}$ following ingestion) is the main diagnostic tool to guide the clinician for the need of further interventions. The grade of injury based upon careful endoscopic assessment appears to closely correlate with urgency for surgical intervention and the development of subsequent complications. It seems that finding of an IIa or lesser grade burn portended a complication free clinical course while grade IIb and III may progress and result in the development of late complication. III $^{\text {rd }}$ degree burns generally suggest the need for urgent surgical intervention [26-29]. Despite the high correlation of the endoscopic findings to the clinical outcomes less than $60 \%$ of physicians use the injury grading assessment. It should be noted that in $10-30 \%$ of adult patients who underwent endoscopy and diagnosed with severe burns and therefore subjected to surgery, exploration and pathology will reveal only minor injury. These findings suggest that endoscopy findings alone may lead to $10-15 \%$ unnecessary surgical procedures [30-33].

As result of tissue edema and inflammation, delayed endoscopy $(>48 \mathrm{~h}$ ) should be avoided because of increased risk of perforation. Recent experience supports the accuracy of CT scan as a diagnostic tool with $75 \%$ sensitivity and $90 \%$ specificity in determining injury grade, need for surgical intervention and ability to predict complications [34-36]. CT scan is noninvasive and may replace endoscopy for triage of patients for immediate surgery in some cases. For example in asymptomatic or mild symptomatic children in which the risk of significant damage to the esophagus or stomach is $<2 \%$ a routine endoscopy may be avoided and CT assessment encouraged [37,38]. More study is needed to determine the role of CT scan in the management algorithm of patients suffering CMI.

\section{Initial treatment}

Treatment of patients after ingestion of caustic material should adhere to basic principles of management of the injured. Air- way management is of utmost importance as edema may develop leading to difficult intubation. Early intubation should be considered in patients with signs and symptoms of upper air- way compromise.

Most patients with significant injury are treated with naso-gastric tube. The tube can be inserted during endoscopy. The theoretical advantage of this practice is to maintain luminal integrity, minimize stricture formation, and provide a continuous route for enteral nutrition but there is no true evidence to support it [39-41].

Antibiotics should be used only when infection is suspected or when steroid treatment is needed [42-46].

Theoretically steroid administration may reduce collagen formation and eventually stricture formation. Clinical trials have failed to prove this. In ccurrent clinical practice steroid use is limited to patients with established respiratory tract edema [47-56].

Peritonitis and presence of pneumoperitoneum or any other clinical or radiological evidence of esophageal or gastric perforation or ischemia are indications for immediate surgical intervention. Bleeding due to necrosis may develop several days after the initial admission and is a late indication for urgent surgical intervention [57-59]. The need for emergency surgery in the management of caustic injuries has a persistent long-term negative impact on survival and functional outcome. When there are no clear indications for emergency operation conservative management with special attention to selective nonsurgical management of pleural effusion, fluid collections, abscesses or micro perforation using percutaneous drainage or esophageal stent is encouraged and may result in better immediate and long terms outcome [60,61]. Major resectional surgeries should be avoided unless hard evidence exists of tissue necrosis or perforation as a result.

\section{Late complication and treatment}

The most common late complication of CMI is gastric outlet obstruction and esophageal stricture. Over $90 \%$ of patients with grade 3 injury and about $30-70 \%$ of patients with grad $2 \mathrm{~B}$ will develop esophageal stricture. Gastric outlet obstruction has been described in about $60 \%$ of patients with grade IIB-III injury in the stomach. Strictures usually develop within 8 weeks after the ingestion but stricture formation as early as 3 weeks after or as late as one year after the caustic material ingestion were reported $[62,63]$. The time of dilatation of the stricture play a central role in achieving a good functional outcome.

Endoscopy dilation should be avoided within the early two weeks after the injury because of the high risk of perforation. Late management is usually associated with marked esophageal wall fibrosis, which makes dilatation more complex Recurrent strictures needing esophageal replacement is significantly more common after delayed dilatation. Dilatation of a stricture 4-6 weeks after CMI is considered more safe and effective. Dilatation of a stricture can be carried out with balloon or Bougies dilators. Bougies dilators are considered more reliable than balloon dilators in consolidated and fibrotic strictures. Long strictures should be treated surgically.

The interval between dilatations is usually 3-4 weeks. Good nutritional status is mandatory for successful outcome [64-68]. Late reconstructive surgery is carried out only in cases where esophageal or gastric dilatation is not possible or dammed hazardous. For esophageal stricture, partial or total esophagectomy with gastric pull up or colonic interposition should be considered. The native esophagus can be left or removed. A 3-30\% incidence of esophageal cancer after by-pass and the unfeasibility of endoscopic follow-up are arguments for favoring removal of the native esophagus in children and young adults. Conversely, the doubled mortality rate $(11.0 \%$ vs $5.9 \%)$ of resection $v s$ by-pass and the associated inadvertent damage to the trachea and laryngeal nerves support a conservative strategy especially in adult patients. The surgical treatment for gastric outlet obstruction is simple pyloroplasty for moderate strictures and gastrojejunostomy or partial gastrectomy for more extensive stricture [69-71].

\section{Conclusion}

Caustic material ingestion may posse life threatening injuries. Current trends in the evaluation and management of patients sustaining CMI suggest a more conservative algorithm. Endoscopic evaluation of the depth of injury is still practiced and considered hallmark toll of management strategy triage. Tomography according to recent experience may replace endoscopy but more controlled studies are needed to confirm this paradigm shift. Immediate surgery should be reserved only for patients with obvious tissue necrosis, perforation or bleeding. Non-operative management for the others will result in better early and long term outcomes. We believe that clinical judgment, selective use of investigational tools and treatment. The role of CT and late outcome of non-operative management should be evaluated in multicenter prospective studies. 
Citation: Katz A, Kluger Y (2015) Caustic Material Ingestion Injuries- Paradigm Shift in Diagnosis and Treatment. Health Care Current Reviews 3: 152. doi: $10.4172 / 2375-4273.1000152$

\section{References}

1. Gumaste VV, Dave PB (1992) Ingestion of corrosive substances by adults. Am J Gastroenterol 87: 1-5

2. Watson WA, Litovitz TL, Rodgers GC, Klein-Schwartz W, Reid N, et al. (2005): 2004 annual report of the american association of poison control centers toxic exposure surveillance system. Am J Emerg Med 23:589-666.

3. Dantas RO, Mamede RC (1996) Esophageal motility in patients with esophageal caustic injury. Am J Gastroenterol 91: 1157-1161.

4. McAuley CE, Steed DL, Webster MW (1985) Late sequelae of gastric acid injury. Am J Surg 149: 412-415.

5. Mamede RC, de Mello Filho FV (2001) Ingestion of caustic substances and its complications. Sao Paulo Med J 119: 10-15.

6. Ertekin C, Alimoglu O, Akyildiz H, Guloglu R, Taviloglu K (2004) The results of caustic ingestions. Hepatogastroenterology 51: 1397-1400.

7. Estrera A, Taylor W, Mills LJ, Platt MR (1986) Corrosive burns of the esophagus and stomach: a recommendation for an aggressive surgical approach. Ann Thorac Surg 41: 276-283.

8. Sugawa C, Lucas CE (1989) Caustic injury of the upper gastrointestinal tract in adults: a clinical and endoscopic study. Surgery 106: 802-806.

9. Poley JW, Steyerberg EW, Kuipers EJ, Dees J, Hartmans R, et al. (2004) Ingestion of acid and alkaline agents: outcome and prognostic value of early upper endoscopy. Gastrointest Endosc 60: 372-377.

10. Ramasamy K, Gumaste VV (2003) Corrosive ingestion in adults. J Clin Gastroenterol 37: 119-124.

11. Havanond C, Havanond $P$ (2007) Initial signs and symptoms as prognostic indicators of severe gastrointestinal tract injury due to corrosive ingestion. $J$ Emerg Med 33: 349-353.

12. Zargar SA, Kochhar R, Nagi B, Mehta S, Mehta SK (1992) Ingestion of strong corrosive alkalis: spectrum of injury to upper gastrointestinal tract and natural history. Am J Gastroenterol 87: 337-341.

13. Chaudhary A, Puri AS, Dhar P, Reddy P, Sachdev A, et al. (1996) Elective surgery for corrosive-induced gastric injury. World J Surg 20: 703-706.

14. Ceylan H1, Ozokutan BH, Gündüz F, Gözen A (2011) Gastric perforation after corrosive ingestion. Pediatr Surg Int 27: 649-653.

15. Ananthakrishnan N, Parthasarathy G, Kate V (2011) Acute corrosive injuries of the stomach: a single unit experience of thirty years. ISRN Gastroentero 2011: 914013

16. Tseng YL, Wu MH, Lin MY, Lai WW (2004) Massive upper gastrointestinal bleeding after acid-corrosive injury. World J Surg 28: 50-54

17. Sarfati E, Gossot D, Assens P, Celerier M (1987) Management of caustic ingestion in adults. Br J Surg 74: 146-148.

18. Berthet B, Castellani P, Brioche MI, Assadourian R, Gauthier A (1996) Early operation for severe corrosive injury of the upper gastrointestinal tract. Eur $\mathrm{J}$ Surg 162: 951-955

19. Turner A, Robinson P (2005) Respiratory and gastrointestinal complications of caustic ingestion in children. Emerg Med J 22: 359-361.

20. Ofri A, Harvey JG, Holland AJ (2013) Pediatric upper aero-digestive and respiratory tract burns. Int J Burns Trauma 3: 209-213.

21. Rigo GP, Camellini L, Azzolini F, Guazzetti S, Bedogni G, et al. (2002) What is the utility of selected clinical and endoscopic parameters in predicting the risk of death after caustic ingestion? Endoscopy 34: 304-310.

22. Cheng YJ, Kao EL (2003) Arterial blood gas analysis in acute caustic ingestion injuries. Surg Today 33: 483-485.

23. Katzka DA1 (2001) Caustic Injury to the Esophagus. Curr Treat Options Gastroenterol 4: 59-66.

24. Di Costanzo J, Noirclerc M, Jouglard J, Escoffier JM, Cano N, et al. (1980) New therapeutic approach to corrosive burns of the upper gastrointestinal tract. Gut 21: $370-375$

25. Zargar SA, Kochhar R, Mehta S, Mehta SK (1991) The role of fiberoptic endoscopy in the management of corrosive ingestion and modified endoscopic classification of burns. Gastrointest Endosc 37: 165-169.
26. Poley JW, Steyerberg EW, Kuipers EJ, Dees J, Hartmans R, et al. (2004) Ingestion of acid and alkaline agents: outcome and prognostic value of early upper endoscopy. Gastrointest Endosc 60: 372-377.

27. Previtera C, Giusti F, Guglielmi M (1990) Predictive value of visible lesions (cheeks, lips, oropharynx) in suspected caustic ingestion: may endoscopy reasonably be omitted in completely negative pediatric patients? Pediatr Emerg Care 6:176-178.

28. Tekant G, EroÄŸlu E, ErdoÄŸan E, YeÅŸildaÄ̈̈ E, Emir H, et al. (2001) Corrosive injury-induced gastric outlet obstruction: a changing spectrum of agents and treatment. J Pediatr Surg 36: 1004-1007

29. Hawkins DB, Demeter MJ, Barnett TE (1980) Caustic ingestion: controversies in management. A review of 214 cases. Laryngoscope 90: 98-109.

30. Keh SM, Onyekwelu N, McManus K, McGuigan J (2006) Corrosive injury to upper gastrointestinal tract: Still a major surgical dilemma. World $\mathrm{J}$ Gastroenterol 12: 5223-5228

31. Isbister GK, Page CB (2011) Early endoscopy or CT in caustic injuries: a reevaluation of clinical practice. Clin Toxicol (Phila) 49: 641-642.

32. Chirica M, Resche-Rigon M, Bongrand NM, Zohar S, Halimi B, et al. (2012) Surgery for caustic injuries of the upper gastrointestinal tract. Ann Surg 256 994-1001.

33. Núñez O, González-Asanza C, de la Cruz G, Clemente G, Bañares R, et al. (2004) [Study of predictive factors of severe digestive lesions due to caustics ingestion]. Med Clin (Barc) 123: 611-614.

34. Isbister GK, Page CB (2011) Early endoscopy or CT in caustic injuries: a reevaluation of clinical practice. Clin Toxicol (Phila) 49: 641-642.

35. Ryu HH, Jeung KW, Lee BK, Uhm JH, Park YH, et al. (2010) Caustic injury: can CT grading system enable prediction of esophageal stricture? Clin Toxicol (Phila) 48: 137-142.

36. Lurie Y, Slotky M, Fischer D, Shreter R, Bentur Y (2013) The role of chest and abdominal computed tomography in assessing the severity of acute corrosive ingestion. Clin Toxicol (Phila) 51: 834-837.

37. Betalli P, Falchetti D, Giuliani S (2008) Caustic ingestion in children: is endoscopy always indicated? The results of an Italian multicenter observational study. Gastrointest Endosc 68: 434-439.

38. Aronow SP, Aronow HD, Blanchard T, Czinn S, Chelimsky G (2003) Hai relaxers: a benign caustic ingestion? J Pediatr Gastroenterol Nutr 36: 120-125

39. Mamede RC, De Mello Filho FV (2002) Treatment of caustic ingestion: an analysis of 239 cases. Dis Esophagus 15: 210-213.

40. Wijburg FA, Beukers MM, Heymans HS, Bartelsman JF, den Hartog Jager FC (1985) Nasogastric intubation as sole treatment of caustic esophageal lesions. Ann Otol Rhinol Laryngol 94: 337-341

41. GÃ $1 / 4 n$ F, AbbasoÄŸlu L, Celik A, Salman ET (2007) Early and late term management in caustic ingestion in children: a 16-year experience. Acta Chir Belg 107: 49-52

42. KREY H (1952) On the treatment of corrosive lesions in the oesophagus; an experimental study. Acta Otolaryngol Suppl 102: 1-49.

43. Salzman M, O'Malley RN (2007) Updates on the evaluation and management of caustic exposures. Emerg Med Clin North Am 25: 459-476.

44. Rao RB, Hoffman RS (2002) Caustic and batteries. In: Goldfrank LR Flomenbaum NE, Lewin NA, Howland MA, Hoffman RS, Nelson LS. (7thedn), Mcgrawth Hill, New York.

45. Kay M, Wyllie R (2009) Caustic ingestions in children. Curr Opin Pediatr 21 651-654.

46. Cheng HT, Cheng CL, Lin CH, Tang JH, Chu YY, et al. (2008) Caustic ingestion in adults: the role of endoscopic classification in predicting outcome. BMC Gastroenterol 8: 31.

47. Lew RJ, Kochman ML (2002) A review of endoscopic methods of esophagea dilation. J Clin Gastroenterol 35: 117-126.

48. Kirsh MM, Ritter F (1976) Caustic ingestion and subsequent damage to the oropharyngeal and digestive passages. Ann Thorac Surg 21: 74-82.

49. Bautista A1, Tojo R, Varela R, Estevez E, Villanueva A, et al. (1996) Effects of prednisolone and dexamethasone on alkali burns of the esophagus in rabbit. $J$ Pediatr Gastroenterol Nutr 22: 275-283. 
Citation: Katz A, Kluger Y (2015) Caustic Material Ingestion Injuries- Paradigm Shift in Diagnosis and Treatment. Health Care Current Reviews 3: 152. doi: $10.4172 / 2375-4273.1000152$

50. Nuutinen M, Uhari M, Karvali T, Kouvalainen K (1994) Consequences of caustic ingestions in children. Acta Paediatr 83: 1200-1205.

51. Anderson KD, Rouse TM, Randolph JG (1990)A controlled trial of corticosteroids in children with corrosive injury of the esophagus. N Engl J Med 323: 637-640.

52. Karnak I, Tanyel FC, Büyükpamukçu N, Hiçsönmez A (1999) Combined use of steroid, antibiotics and early bougienage against stricture formation following caustic esophageal burns. J Cardiovasc Surg (Torino) 40: 307-310.

53. Bautista A, Varela R, Villanueva A, Estevez E, Tojo R, et al. (1996) Effects of prednisolone and dexamethasone in children with alkali burns of the oesophagus. Eur J Pediatr Surg 6: 198-203.

54. Usta M, Erkan T, Cokugras FC, Urganci N, Onal Z, et al. (2014) High doses of methylprednisolone in the management of caustic esophageal burns. Pediatrics 133: E1518-1524.

55. Pelclová D, Navrátil T (2005) Do corticosteroids prevent oesophageal stricture after corrosive ingestion? Toxicol Rev 24: 125-129.

56. Fulton JA, Hoffman RS (2007) Steroids in second degree caustic burns of the esophagus: a systematic pooled analysis of fifty years of human data: 19562006. Clin Toxicol (Phila) 45: 402-408.

57. Andreoni B, Farina ML, Biffi R, Crosta C (1997) Esophageal perforation and caustic injury: emergency management of caustic ingestion. Dis Esophagus 10: 95-100.

58. Cattan P, Munoz-Bongrand N, Berney T, Halimi B, Sarfati E, et al. (2000) Extensive abdominal surgery after caustic ingestion. Ann Surg 231: 519-523.

59. Wu MH, Lai WW (1993) Surgical management of extensive corrosive injuries of the alimentary tract. Surg Gynecol Obstet 177: 12-16.

60. Søreide JA, Viste A (2011) Esophageal perforation: diagnostic work-up and clinical decision-making in the first 24 hours. Scand J Trauma Resusc Emerg Med 19: 66.

61. Freeman RK, Van Woerkom JM, Vyverberg A, Ascioti AJ (2009) Esophageal stent placement for the treatment of spontaneous esophageal perforations. Ann Thorac Surg 88: 194-198.
62. Gupta V, Wig J D, Kochhar R (2009) "Surgical management of gastric cicatrisation resulting from corrosive ingestion," International Journal of Surgery 7: 257-261.

63. Contini S, Scarpignato $C$ (2013) Caustic injury of the upper gastrointestinal tract: a comprehensive review. World J Gastroenterol 19: 3918-3930.

64. Lung-Sheng Lu, Wei-Chen Ta, Ming-Luen Hu, Keng-Liang Wu, Yi-Chun Chiu (2014) Predicting the Progress of Caustic Injury to Complicated Gastric Outlet Obstruction and Esophageal Stricture, Using Modified Endoscopic Mucosal Injury Grading Scale.

65. Lahoti D, Broor SL, Basu PP, Gupta A, Sharma R, et al. (1995) Corrosive esophageal strictures: predictors of response to endoscopic dilation. Gastrointest Endosc 41: 196-200.

66. Kim YT, Sung SW, Kim JH (2001) Is it necessary to resect the diseased esophagus in performing reconstruction for corrosive esophageal stricture? Eur J Cardiothorac Surg 20: 1-6.

67. Gerzic ZB, Knezevic JB, Milicevic MN, Jovanovic BK (1990) Esophagocoloplasty in the management of postcorrosive strictures of the esophagus. Ann Surg 211: 329-336.

68. Pace F, Antinori S, Repici A (2009) What is new in esophageal injury (infection, drug-induced, caustic, stricture, perforation)? Curr Opin Gastroenterol 25:372379.

69. Panieri E, Rode H, Millar AJ, Cywes S (1998) Oesophageal replacement in the management of corrosive strictures: when is surgery indicated? Pediatr Surg Int 13: 336-340.

70. Okonta KE, Tettey M, Abubakar U (2012) In patients with corrosive oesophageal stricture for surgery, is oesophagectomy rather than bypass necessary to reduce the risk of oesophageal malignancy? Interact Cardiovasc Thorac Surg15: 713-715

71. Gupta NM, Gupta R (2004) Transhiatal esophageal resection for corrosive injury. Ann Surg 239: 359-363. 